\title{
The Pharmacology of Sulphetrone and Its Implications in Sulphone Resistance
}

\author{
ROBERT H. GELBER* \\ H. C. GOOI \\ M. F. R. WATERS \\ Leprosy Research Unit, National Leprosy Control \\ Center, Sungei Buloh, Selangor, Malaysia \\ and \\ R. J. W. REES
Laboratory for Leprosy and Mycobacterial Research, National Institute for Medical Research, Mill Hill, London NW7 IAA

\begin{abstract}
Spectrofluorometric techniques were utilized to quantitate dapsone (DDS) and $\mathrm{N}^{4}$-acetyldapsone (MADDS) contamination of a sulphetrone preparation used for leprosy in Malaysia between 1947 and 1951. Also plasma levels of DDS and MADDS following administration of a standard intramuscular dose of this preparation were studied. The preparation was contaminated with trace amounts of DDS but no MADDS. Following injection the plasma levels were substantial and suggested that sulphetrone was converted in vivo to DDS. The importance of these findings to the problem of sulphone resistance is discussed.
\end{abstract}

\section{Introduction}

Sulphetrone (solapsone), a sulphone, was prepared in 1936 (Buttle et al., 1938) and subsequently attracted attention because of its antituberculosis activity (Brownlee and Kennedy, 1948) and low toxicity (Brownlee, 1948). Sulphetrone was first shown to be effective in the treatment of lepromatous leprosy in 1942 (Harkness and Brownlee, 1948) and was widely used for some 12 years (Dharmendra, 1950; Cochrane et al., 1949; Austin, 1950). However, it fell into disrepute because it is poorly absorbed in the gastrointestinal tract (Smith, $1949 a$ ), causes pain following intramuscular injection, and was thought to act

* Request reprints from Robert H. Gelber, Chief, Infectious Diseases, United States Public Health Service Hospital, 15 th Ave. and Lake St, San Francisco, California 94118 U.S.A.

Received for publication August 1974 
against Mycobacterium leprae only because of contamination with dapsone (DDS) (Lowe, 1952) or conversion in vivo to it (Smith, 1959b). Deavin et al. (1967), utilizing a semiquantitative assay, demonstrated that sulphetrone was contaminated with $0.5-2 \%$ DDS.

A recent retrospective analysis by Meade et al. (1973) of the emergence of sulphone resistance among lepromatous leprosy patients at the National Leprosy Control Center, Sungei Buloh, Malaysia, showed an incidence of $8 \%$ in patients initially treated between 1947 and 1951 with sulphetrone, compared to an incidence of $2 \%$ in patients begun on DDS. Highly sensitive and specific spectrofluorometric techniques for the assay of DDS and its monoacetyl metabolite (MADDS) have now been developed (Peters et al., 1970). We applied these methods to determine the amount of DDS and MADDS in the same sulphetrone preparation used earlier in Malaysia and also to determine plasma concentrations obtained in patients following the usual therapeutic dose of this preparation. It was hoped that information from these studies might prove useful in assessing the efficacy of other sulphone preparations, as well as different DDS regimens.

\section{Methods}

Two vials of aqueous $30 \%$ sulphetrone (Ph Lab Kuala Lumpur) were diluted serially with distilled water to $1 / 2500$ and $1 / 5000$, and the concentrations of DDS and MADDS determined fluorometrically (Peters et al., 1970) in duplicate samples. This method was modified to avoid sulphetrone breakdown by omitting sodium hydroxide during the initial extraction.

Eight adult patients volunteered to discontinue all sulphones for two weeks. After this period a baseline urine was analysed for sulphone conterit by a modification of the procedure of Bratton and Marshall (1939), sensitive to $0.3 \mu \mathrm{g} / \mathrm{ml}$. Five $\mathrm{ml}$ of the $30 \%$ sulphetrone preparation was then injected intramuscularly, and heparinized plasma was obtained generally just before and 4, 8, 24, 48, 72 and $96 \mathrm{~h}$ after administration. Plasma concentrations of DDS and MADDS were determined fluorometrically. No specimens were studied after four days because in Malaysia the standard practice had been to treat leprosy patients with $5 \mathrm{ml}$ sulphetrone twice weekly.

\section{Results}

There was ne ( $0.02 \mathrm{mg} / \mathrm{ml})$ MADDS found in either of the two vials of sulphetrone studied. Duplicate specimens and at the two dilutions studied showed no greater than $1 \%$ discrepancy in the amount of DDS contamination of the sulphetrone preparation. DDS concentration in the two vials was 0.70 and 0.75 $\mathrm{mg} / \mathrm{ml}$.

Plasma levels of DDS and MADDS following a single intramuscular injection of sulphetrone in each of the eight patients studied are presented in Table 1.

\section{Discussion}

These studies confirm that sulphetrone is contaminated with trace amounts of DDS. The average plasma DDS concentrations found in subjects 24 and $48 \mathrm{~h}$ after sulphetrone administration were 93 and $78 \mathrm{mg} / \mathrm{ml}$ respectively. Twenty-four and $48 \mathrm{~h}$ after a $50-\mathrm{mg}$ oral dose of DDS in patients from this institution, the mean 
TABLE 1

MADDS and DDS plasma levels following intramuscular administration of $5 \mathrm{ml} 30 \%$ sulphetrone

\begin{tabular}{|c|c|c|c|c|c|c|c|c|}
\hline \multirow{3}{*}{$\begin{array}{l}\text { Patient } \\
\text { (Wt in } \mathrm{kg})\end{array}$} & \multirow[b]{3}{*}{ Substance } & \multicolumn{7}{|c|}{$\begin{array}{c}\text { Plasma concentration } \\
(\mathrm{mg} / \mathrm{ml})\end{array}$} \\
\hline & & \multicolumn{7}{|c|}{ Hours after injection } \\
\hline & & 0 & 4 & 8 & 24 & 48 & 72 & 96 \\
\hline \multirow{2}{*}{$\begin{array}{l}\text { Indian male } \\
(58.2)\end{array}$} & DDS & - & 90 & 80 & 100 & 80 & & 30 \\
\hline & MADDS & - & 20 & 20 & 20 & 20 & & 10 \\
\hline \multirow{2}{*}{$\begin{array}{l}\text { Chinese female } \\
\quad(40.9)\end{array}$} & DDS & 0 & 100 & 90 & 120 & 120 & & 100 \\
\hline & MADDS & 0 & 70 & 70 & 120 & 120 & & 80 \\
\hline \multirow{2}{*}{$\begin{array}{l}\text { Chinese male } \\
\quad(60.0)\end{array}$} & DDS & 10 & 90 & 90 & 70 & 70 & & \\
\hline & MADDS & 10 & 50 & 50 & 40 & 40 & & \\
\hline \multirow{2}{*}{$\begin{array}{l}\text { Chinese male } \\
(48.2)\end{array}$} & DDS & 10 & 60 & 60 & 60 & 40 & 30 & 10 \\
\hline & MADDS & 20 & 70 & 60 & 50 & 50 & 30 & 20 \\
\hline \multirow{2}{*}{$\begin{array}{l}\text { Chinese male } \\
\quad(53.2)\end{array}$} & DDS & 10 & 70 & 70 & 70 & 70 & 40 & 20 \\
\hline & MADDS & 30 & 40 & 50 & 30 & 30 & 30 & 20 \\
\hline \multirow{2}{*}{$\begin{array}{l}\text { Malay male } \\
\quad(52.0)\end{array}$} & DDS & 0 & - & - & 90 & 60 & 30 & 20 \\
\hline & MADDS & 0 & - & - & 10 & 10 & 0 & 0 \\
\hline \multirow{2}{*}{$\begin{array}{c}\text { Malay male } \\
(48.0)\end{array}$} & DDS & 10 & - & - & 120 & 110 & 100 & 80 \\
\hline & MADDS & 20 & - & - & 60 & 50 & 50 & 30 \\
\hline \multirow{2}{*}{$\begin{array}{l}\text { Chinese male } \\
\quad(48.0)\end{array}$} & DDS & 0 & - & - & 110 & 70 & 40 & 20 \\
\hline & MADDS & 0 & - & - & 80 & 50 & 30 & 20 \\
\hline \multirow[t]{2}{*}{ Average } & DDS & 6 & 82 & 78 & 93 & 78 & 48 & 40 \\
\hline & MADDS & 11 & 50 & 50 & 51 & 46 & 28 & 26 \\
\hline
\end{tabular}

Tests for urinary DDS concentration, sensitive to $0.3 \mu \mathrm{g} \mathrm{ml}$, were negative for all patients before injection of sulphetrone.

plasma levels were 260 and $128 \mathrm{mg} / \mathrm{ml}$ respectively (Gelber and Rees, unpublished results). Since plasma concentration of DDS has been found to be linearly related to dose (Ellard et al., 1971), certainly the 3.5 or $3.75 \mathrm{mg}$ DDS contaminating each sulphetrone injection is too little to account for the circulating levels of DDS. Hence significant in vivo metabolism of sulphetrone to DDS must occur.

Patients treated with the intramuscular repository sulphone acedapsone (DADDS) in the usual dose of $225 \mathrm{mg}$ every 77 days averaged 25 to $31 \mathrm{mg} / \mathrm{ml}$ DDS in the plasma just before the next injection (Murray et al., in press; Gordon et al., in press). As plasma levels of DDS in patients treated with sulphetrone in Malaysia on the average would not have fallen below $40 \mathrm{mg} / \mathrm{ml}$, DADDS therapy of bacilliferous leprosy might similarly result in an unacceptable frequency of relapse with DDS-resistant Myco. leprae. We therefore would be reluctant to recommend DADDS as monotherapy of lepromatous leprosy in areas where other alternatives are possible. 
It has been demonstrated that $1-10 \mathrm{mg} / \mathrm{ml}$ DDS in plasma will prevent multiplication of Myco. leprae in the footpads of mice (Shepard et al., 1969; Ellard et al., 1971) and rats (Peters et al., 1972). Patients treated with sulphetrone maintained levels that were at all times above this minimal inhibitory concentration, and yet $8 \%$ of them relapsed with dapsone-resistant leprosy, which must be considered unacceptable. Thus it may be hazardous to extrapolate from levels of dapsone effective for preventing multiplication in the local self-limited infection in mice and rats to the treatment of the severe and progressive systemic disease that Myco. leprae may cause in man, because of differences in bacterial load and hence the numbers of DDS-resistant mutants. Results from this study suggest that the currently fashionable low-dose DDS regimens may be hazardous.

\section{Acknowledgements}

We acknowledge the technical assistance of Mr Yeoh Chin Aik. Dr Gelber was supported by the University of California International Center for Medical Research through grant AI 10051 to the Department of International Health, School of Medicine, University of California, San Francisco, from the National Institute of Allergy and Infectious Diseases, National Institutes of Health, U.S. Public Health Service. Dr Gelber also acknowledges the support of the Institute for Medical Research, Kuala Lumpur, Malaysia. The Leprosy Research Unit, Sungei Buloh, Malaysia, is jointly administered by the (British) Medical Research Council and the Malaysian Ministry of Health.

\section{References}

Austin, C. J. (1950). Effects of sulphetrone treatment in Fiji. Int. J. Lepr. 18, 345.

Bratton, A. C. and Marshall, E. K. (1939). A new coupling component for sulfanilamide determination. J. biol. Chem. 128, 537.

Brownlee, G. (1948). Sulphetrone: Therapeutics and toxicology. Lancet ii, 131.

Brownlee, G. and Kennedy, C. R. (1948). The treatment of experimental tuberculosis with sulphetrone. Brit. J. Pharmacol. Chemother. 3, 29.

Buttle, G. A. H., Dewing, T., Foster, G. E., Gray, W. H., Smith, S. and Stephenson, D. (1938). The action of substances allied to $4: 4^{\prime}$-diaminodiphenylsulphone in streptococcal and other infections in mice. Biochem. J. 32, 1101 .

Cochrane, R. G., Ramanujam, K., Paul, H. and Russell, D. (1949). Two and a half years' experimental work on the sulphone group of drugs. Lepr. Rev. 20, 4.

Deavin, J. C., Drey, R. E. A. and Foster, G. E. (1967). The chemical assay of solapsone. J. Pharm. Pharmacol. 19,105 S.

Dharmendra (1950). The results of sulphetrone treatment of leprosy in the Gobra Hospital, Calcutta. Lepr. India 22, 46.

Ellard, G. A., Gammon, P. T., Rees, R. J. W. and Waters, M. F. R. (1971). Studies on the determination of the minimal inhibitory concentration of $4,4^{\prime}$-diamino-diphenyl-sulphone (Dapsone, DDS) against Mycobacterium leprae. Lepr. Rev. 42, 101.

Gordon, G. R., Murray, J. F., Peters, J. H., Russell, D. A. and Vincin, D. R. (In press). Plasma levels of sulfones in patients of Papua New Guinea receiving acedapsone: correlation with clinical assessment. Int. J. Lepr.

Harkness, A. H. and Brownlee, G. (1948). Leprosy treated with sulphetrone in 1943. Proc. roy. Soc. Med. 41, 309.

Lowe, J. (1952). Studies in sulphone therapy. Lepr. Rev. $23,2$.

Meade, T. W., Pearson, J. M. H., Rees, R. J. W. and North, W. R. S. (1973). The epidemiology of sulphone resistant leprosy. Abstr. Tenth International Leprosy Congress, Bergen, p.332.

Murray, J. F., Gordon, G. R., Peters, J. H., Levy, L. and Prochazka, G. J. (In press). Metabolism and clearance of dapsone, monoacetyldapsone and acedadapsone in Filipino leprosy patients receiving acedapsone.Int. J. Lepr. 
Peters, J. H., Gordon, G. R. and Colwell, W. T., Jr (1970). The fluorometric measurement of $4,4^{\prime}$-diaminodiphenyl sulfone and its acetylated derivatives in plasma and urine. J. Lab. clin. Med. 76, 338.

Peters, J. H., Gordon, G. R., Murray, J. F., Jr, Fieldsteel, A. H. and Levy, L. (1972). Minimal inhibitory concentration of dapsone for Mycobacterium leprae in rats. Int. J. Lepr. 40, 467.

Shepard, C. C., Levy, L. and Fasal, P. (1969). The sensitivity to dapsone (DDS) of Mycobacterium leprae from patients with and without previous treatment. Amer. J. trop. Med. Hyg. 18, 258.

Smith, M. (1949a). A pharmacological study of three sulphones. Part 1-Absorption, distribution and excretion. Lepr. Rev. 20, 78.

Smith, M. (1949b). A pharmacological study of three sulphones. Part 2. Lepr. Rev. 20, 128. 